\title{
Retraction of articles written by Dr. Yoshitaka Fujii
}

\author{
Donald R. Miller, MD
}

Received: 12 September 2012/ Accepted: 21 September 2012/Published online: 10 October 2012

(c) Canadian Anesthesiologists' Society 2012

On March $13^{\text {th }}, 2012$, an Expression of Concern was posted in the Journal regarding 39 published articles written by Dr. Yoshitaka Fujii from Japan. ${ }^{\text {A }}$ The notice explained that the Editorial Office had received an article submission entitled "Effects of colforsin daropate on hypercapnic depression of diaphragmatic contractility in pentobarbitalanesthetized dogs". The authors of the article are Yoshitaka Fujii MD and Aki Uemura MD from the First Department of Anesthesiology, Toho University School of Medicine in Tokyo, Japan. At the time the article was submitted, the editors of the Journal were aware of ongoing concerns regarding Dr. Fujii's work that extended over the previous two decades. Indeed, a Letter to the Editor by Kranke et al. ${ }^{1}$ published in Anesthesia \& Analgesia in 2000 raised serious concerns regarding the implausibility of data in 47 articles by Dr. Fujii published in five journals, including the Canadian Journal of Anesthesia, during the years 1994-99. In 13 of the articles cited by Kranke et al., the frequency of headache was reported as being identical in all groups, whereas this side effect differed by no more than one patient per group in the remaining eight papers. Statistical testing of the null hypothesis that the reported identical incidences could have occurred by chance $v s$ the alternative hypothesis that an underlying reason led to such identical results led Kranke et al. to their conclusion that

Electronic supplementary material The online version of this article (doi:10.1007/s12630-012-9802-9) contains supplementary material, which is available to authorized users.

D. R. Miller, MD ( $\varangle)$

Editorial Office, Canadian Journal of Anesthesia, c/o The Ottawa Hospital and University of Ottawa, The Ottawa Hospital,

General Campus CCW, Room 1409, 501 Smyth Road, Ottawa,

ON K1H 8L6, Canada

e-mail: dmiller@ottawahospital.on.ca "there must be an underlying influence causing such incredibly nice data reported by Fujii et al." ${ }^{1}$ In retrospect, we deeply regret that the affected journals did not pursue these concerns at that time.

Looking back to 2011, I alerted Dr. Ryoichi Ochiai, Professor of Anesthesiology at Toho University School of Medicine, to concerns regarding the implausibility of certain elements of the data presented in Dr. Fujii's manuscript on colforsin daropate submitted to the Journal. This notification triggered the launch of an internal investigation at Toho University. I was subsequently advised that Dr. Fujii's article had no ethically approved protocol, and furthermore, there would be no means to prove the authenticity of the data or the validity of the study itself. The Journal rejected this article as a result of the departmental investigation, leaving the extent of further actions to be determined by the University. Shortly thereafter, a more extensive review of Dr. Fujii's work was launched by the Investigating Committee of the Faculty of Medicine at Toho University. The University Discipline Committee's findings were released in March 2012 and referred to studies (Appendix, available as Electronic Supplementary Material) published in other journals that had been conducted without Ethics Committee approval. In its statement, the University exonerated co-author Dr. Michiyo Itakura. Toho University subsequently organized a Disciplinary Committee which ruled disciplinary dismissal appropriate, and Dr. Fujii was summarily dismissed on February 29, 2012.

In March 2012, a detailed and innovative analysis of 168 randomized controlled trials written by Dr. Fujii from 1999-2011 as either primary author or a co-author was

\footnotetext{
A http://www.springer.com/journal/12630 (accessed September 1, 2012).
} 
published in Anaesthesia. ${ }^{2}$ This analysis, written by Dr. John Carlisle, provides an overwhelming statistical argument that "the distribution of continuous and categorical variables reported in Fujii's papers, both animal and human, are extremely unlikely to have arisen by chance and, if so, in many cases with likelihoods that are infinitesimally small." The analysis showed that the published distributions of 28/33 variables across studies were encountered with expected distributions such that "their likelihood of occurrence ranged from one in 25 to less than one in $10^{33}$ ".

On behalf of the editors of the affected journals, Dr. Steven Shafer, Editor-in-Chief of Anesthesia \& Analgesia, wrote the Deans of the Faculties of Medicine of the six universities in Japan from which Dr. Fujii had prior affiliations to alert the institutions of these concerns and to notify them of the articles written by Dr. Kranke et al. and Dr. Carlisle. ${ }^{\mathrm{B}}$ The universities were asked to provide unequivocal evidence of Institutional Review Board approval and data veracity regarding each of the 168 studies cited in the Carlisle article plus an additional 23 suspect papers. In their Joint Statement, the editors identified that the review would be complex as it involved a number of institutions, and they emphasized that, "in the absence of the aforementioned documentation, it is possible that many or all of the affected articles may be retracted in due course."

Over the ensuing months, the institutions in Japan reported their findings. The JA Toride Medical Center found no documentation or Institutional Review Board (IRB) approval for any of the 49 articles written by Dr. Fujii while he was at that centre. Toho University reported that eight of 25 articles they reviewed had no evidence of IRB approval, and furthermore, 11 of the 25 articles were review articles that made reference to some of Dr. Fujii's problematic papers; hence, the investigating committee did not recognize the scientific propriety of these articles either. Tokyo Medical and Dental University investigated 13 articles; three of the articles were deemed to have been cases of properly conducted studies where Dr. Fujii's name had been added as a "gift authorship". The University of Tsukuba reported that five of 97 papers from their institution are legitimate. Their investigations of the remaining 92 papers are ongoing.

Concurrently, and quite independently, the Japanese Society of Anesthesiologists (JSA) established its own Special Investigating Committee, which consists of a group of editors representing 23 journals that examined 212 articles written by Dr. Fujii. The Committee investigated original research data, laboratory notebooks, and the relevant records

\footnotetext{
B http://www.aaeditor.org/Fujii_Joint_EIC_Stmt.pdf (accessed August $25,2012)$.
}

at institutions. In addition, members of the Committee interviewed Dr. Fujii and the co-authors listed in his papers. On June 29, 2012, the Japanese Society of Anesthesiologists released the Committee's statement entitled "The Results of the Investigation into Dr. Yoshitaka Fujii's Papers". C Three of the 192 manuscripts listed in the Editors' Joint Statement ${ }^{\mathrm{B}}$ are considered valid (all three were published in the Journal); 154 articles published across multiple journals are likely fraudulent, and there is a shortage of data to evaluate 28 papers. Based on the findings of the investigating bodies, a Retraction Notice was posted on the Journal's website on September 8, 2012 stating that:

"Further to the Expression of Concern posted online on March $13^{\text {th }}, 2012$, the 17 articles listed in Table 1 by Dr. Yoshitaka Fujii are hereby retracted as a result of:

1) overwhelming evidence of fabrication relating to the fact that the distributions of many variables reported by Dr. Fujii in these studies are exceedingly unlikely $^{1,2}$; and

2) the inability of Dr. Fujii's institutions to attest to the integrity of the studies and/or the data conducted under their auspices, as set out in the Joint Editors-in-Chief Request for Determination of April 9, 2012. ${ }^{\text {B }}$

The notice also explains that the University of Tsukuba has affirmed the validity of three articles ${ }^{3-5}$ published in the Journal that were written by Dr. S. Takahashi and co-authored by Dr. Fujii. In addition, Tokyo Medical and Dental University affirmed the legitimacy of two other articles published in the Journal; one article was written by Dr. T. Ebata ${ }^{6}$ and the other by Dr. Y. Saitoh ${ }^{7}$; both articles were co-authored by Dr. Fujii. The above five articles shall remain part of the unimpeached medical literature. Individual retraction notes for each of the 17 articles listed in Table 1 appear in this issue of the Journal. The 17 articles by Dr. Fujii listed in Table 2 remain under review by the University of Tsukuba and are considered compromised until they are assessed by the University. Articles in Table 2 that are not affirmed as valid by the University of Tsukuba will be retracted.

It is usually considered to be the responsibility of universities to investigate cases of suspected scientific and/or ethical misconduct and to take appropriate disciplinary action when such cases are confirmed. It is the duty of the affected journals to undertake the retractions. While journals generally recognize only the findings of institutional investigations, in this instance, the Japanese Society of Anesthesiologists ' investigation extended and corroborated the findings of the investigating committees at the

\footnotetext{
${ }^{\mathrm{C}}$ http://www.anesth.or.jp/english/pdf/news20120629.pdf (accessed September 7, 2012).
} 
Table 1 Articles retracted from the Canadian Journal of Anesthesia

1. Fujii Y, Tanaka H, Toyooka H. Granisetron reduces postoperative nausea and vomiting throughout menstrual cycle. Can J Anaesth 1997; 44: 489-93.

2. Fujii $Y$, Tanaka H, Toyooka $H$. Granisetron reduces the incidence and severity of nausea and vomiting after laparoscopic cholecystectomy. Can J Anaesth 1997; 44: 396-400.

3. Fujii $Y$, Tanaka H, Toyooka H. Prophylactic antiemetic efficacy of granisetron in patients with and without previous postoperative emesis. Can J Anaesth 1997; 44: 273-7.

4. Fujii $Y$, Tanaka H, Toyooka H. Granisetron and dexamethasone provide more improved prevention of postoperative emesis than granisetron alone in children. Can J Anaesth 1996; 43: 1229-32.

5. Fujii $Y$, Toyooka $H$, Tanaka $H$. Antiemetic efficacy of granisetron and metoclopramide in children undergoing ophthalmic or ENT surgery. Can J Anaesth 1996; 43: 1095-9.

6. Fujii Y, Toyooka H, Tanaka H. Effective dose of granisetron for preventing postoperative emesis in children. Can J Anaesth 1996; 43: 660-4.

7. Fujii $Y$, Toyooka H, Tanaka $H$. Antiemetic effects of granisetron on postoperative nausea and vomiting in patients with and without motion sickness. Can J Anaesth 1996; 43: 110-4.

8. Fujii Y, Tanaka H, Toyooka H. Granisetron reduces vomiting after strabismus surgery and tonsillectomy in children. Can J Anaesth 1996; 43: $35-8$.

9. Fujii $Y$, Tanaka $H$, Toyooka $H$. Prevention of postoperative nausea and vomiting with granisetron: a randomised, double-blind comparison with droperidol. Can J Anaesth 1995; 42: 852-6.

10. Fujii $Y$, Tanaka H, Saitoh $Y$, Toyooka $H$. Effects of calcium channel blockers on circulatory response to tracheal intubation in hypertensive patients: nicardipine versus diltiazem. Can J Anaesth 1995; 42: 785-8.

11. Fujii Y, Tanaka H, Toyooka H. Granisetron-dexamethasone combination reduces postoperative nausea and vomiting. Can J Anaesth 1995; 42: 387-90.

12. Fujii Y, Toyooka H, Amaha K. Amrinone improves contractility of fatigued diaphragm in dogs. Can J Anaesth 1995; 42: 80-6.

13. Fujii $Y$, Tanaka $H$, Toyooka $H$. Circulatory responses to laryngeal mask airway insertion or tracheal intubation in normotensive and hypertensive patients. Can J Anaesth 1995; 42: 32-6.

14. Fujii Y, Tanaka H, Toyooka H. Optimal anti-emetic dose of granisetron for preventing postoperative nausea and vomiting. Can J Anaesth 1994; 41: 794-7.

15. Fujii Y, Toyooka H, Amaha K. Nicardipine enhances diaphragmatic fatigue. Can J Anaesth 1994; 41: 435-9.

16. Fujii Y, Tanaka H, Toyooka H. Reduction of postoperative nausea and vomiting with granisetron. Can J Anaesth 1994; 41 : 291-4.

17. Fujii Y, Toyooka H, Ebata T, Amaha K. Contractility of fatigued diaphragm is improved by dobutamine. Can J Anaesth 1993; 40: 453-8.

universities where Dr. Fujii had previously worked. In addition, the Japanese Society of Anesthesiologists' statement also addresses how Dr. Fujii could have published so many fabricated articles. The statement is made that, "In order to be easily accepted by journals, he [Dr. Fujii] fabricated in most his papers that he studied large numbers of cases in a randomized controlled trial in double-blind manner." In addition, "the name of the institution and the period of study have not been specific in his papers so that 'he could excuse that the data were obtained at a previously worked hospital or in a place where he took a part-time job'." In many articles, the affiliated institutions of the research ethics boards were not identified, and furthermore, Dr. Fujii made it appear that many articles were multiauthored studies by placing names of other institutions along with his list of co-authors. The Japanese Society of Anesthesiologists' statement also states that "all fabrications were done by Dr. Fujii alone". The reason he included the names of co-authors on the papers was apparently a tactic "to escape from suspicions of fraud".

We deeply regret the negative impact that will be generated by retracting such a large body of scientific literature from this journal and others. These retractions, and others yet to come, occur just a little more than a year following retraction of the Boldt articles. ${ }^{8}$ Twelve of the 17 articles written by Dr. Fujii that have now been retracted describe clinical trials in adult and pediatric populations ostensibly evaluating the antiemetic efficacy of granisetron. Three of these 17 studies describe results relating to the efficacy of various pharmacological interventions, including dobutamine, nicardipine, and amrinone, to attenuate diaphragmatic fatigue in a canine model. In general, health practice and policy is rarely changed based on the results of a single primary study. More often, changes in clinical practice evolve gradually after one or more systematic reviews or practice guidelines (resulting from a systematic review). In the case of Dr. Fujii's retracted articles, it will be important to ascertain the impact of his primary research that has been included in systematic reviews, as such results could be potentially misleading until such time as they can be re-analyzed without the problem primary studies.

On behalf of the Journal's Editorial Board, we extend our sincerest thanks to the universities in Japan that undertook the very difficult task to investigate. In particular, we extend our appreciation to Dr. Ryoichi Ochiai, Professor of Anesthesiology at Toho University in Japan, 
Table 2 Articles written by Dr.Yoshitaka Fujii which are indeterminate

1. Fujii $Y$, Nakayama M. A lidocaine/metoclopramide combination decreases pain on injection of propofol. Can J Anesth 2005; 52: 474-7.

2. Numazaki M, Fujii Y. Antiemetic efficacy of propofol at small doses for reducing nausea and vomiting following thyroidectomy. Can J Anesth 2005; 52: 333-4.

3. Fujii Y. Pretreatment with flurbiprofen axetil and venous occlusion to reduce pain during injection of propofol. Can J Anesth 2004; 51: 1047-8.

4. Nakano M, Fujii $Y$. Prevention of nausea and vomiting after dental surgery: a comparison of small doses of propofol, droperidol, and metoclopramide. Can J Anesth 2003; 50: 1085.

5. Fujii Y, Toyooka H. High-dose colforsin daropate increases diaphragmatic contractility in dogs. Can J Anesth 2002; 49; 877-9.

6. Saitoh Y, Kaneda K, Fujii Y, Oshima T. Nicorandil accelerates recovery of neuromuscular block caused by vecuronium. Can J Anesth 2001; 48: 28-33.

7. Fujii $Y$, Toyooka H. Different effects of olprinone on contractility in nonfatigued and fatigued diaphragm in dogs. Can J Anesth 2000; 47: 1243-8.

8. Hoshi T, Fujii Y, Takahashi S, Toyooka H. Effect of xenon on diaphragmatic contractility in dogs. Canadian Can J Anesth 2000; 47: 819-22.

9. Fujii $Y$, Saitoh $Y$, Tanaka H, Toyooka $H$. Ramosetron vs granisetron for the prevention of postoperative nausea and vomiting after laparoscopic cholecystectomy. Can J Anesth 1999; 46: 991-3

10. Fujii Y, Saitoh Y, Takahashi S, Toyooka H. Combined diltiazem and lidocaine reduces cardiovascular responses to tracheal extubation and anesthesia emergence in hypertensive patients. Can J Anesth 1999; 46: 952-6.

11. Fujii $Y$, Saitoh $Y$, Takahashi S, Toyooka H. Diltiazem-lidocaine combination for the attenuation of cardiovascular responses to tracheal intubation in hypertensive patients. Can J Anaesth 1998; 45: 933-7.

12. Fujii Y, Kihara S-I, Takahashi S, Tanaka H, Toyooka H. Calcium channel blockers attenuate cardiovascular responses to tracheal extubation in hypertensive patients. Can J Anaesth 1998; 45: 655-9.

13. Fujii $Y$, Saitoh $Y$, Tanaka H, Toyooka H. Prophylactic antiemetic therapy with granisetron-droperidol combination in patients undergoing laparoscopic cholecystectomy. Can J Anaesth 1998; 45: 541-4.

14. Fujii Y, Saitoh Y, Tanaka H, Toyooka H. Cardiovascular responses to tracheal extubation or LMA removal in children. Can J Anaesth 1998; 45: 178-81.

15. Fujii $Y$, Saitoh Y, Tanaka H, Toyooka H. Prevention of PONV with granisetron, droperidol or metoclopramide in patients with postoperative emesis. Can J Anaesth 1998; 45: 153-6.

16. Fujii $Y$, Toyooka H, Tanaka H. Cardiovascular responses to tracheal extubation or LMA removal in normotensive and hypertensive patients. Can J Anaesth 1997; 44: 1082-6.

17. Fujii Y, Toyooka H, Tanaka H. Prevention of PONV with granisetron, droperidol and metoclopramide in female patients with history of motion sickness. Can J Anaesth 1997; 44: 820-4.

Dr. Steven Shafer, Editor-in-Chief of Anesthesia \& Analgesia, and Dr. Steven Yentis, Editor-in-Chief of Anaesthesia. While an experienced fraudster will always be difficult to detect, we can only hope that greater oversight from all universities, adherence to the requirements of validated reporting guidelines, and greater rigour in editorial peer review will minimize or eliminate the likelihood of such extensive and serial fraud from reoccurring.

\section{Rétraction des articles rédigés par le Dr Yoshitaka Fujii}

Le 13 mars 2012, un énoncé de préoccupations a été publiée dans le Journal concernant 39 articles publiés qui avaient été rédigés par le Dr Yoshitaka Fujii exerçant au Japon. ${ }^{\mathrm{A}}$ Cet avis expliquait que le Bureau éditorial avait

\footnotetext{
${ }^{\mathrm{A}} \mathrm{http}: / / \mathrm{www}$.springer.com/journal/12630 (accessed September 1, 2012).
}

reçu un article, soumis pour publication, intitulé « Effets du colforsin daropate sur la dépression hypercapnique de la contractilité diaphragmatique chez des chiens anesthésiés au pentobarbital ». Les auteurs de l'article étaient le Dr Yoshitaka Fujii et le Dr Aki Uemura du Premier département d'anesthésiologie, de l'École de médecine de l'université Toho, à Tokyo (Japon). Au moment où l'article a été soumis, les rédacteurs du Journal étaient informés des préoccupations concernant le travail du Dr Fujii qui s'étendait sur les deux décennies précédentes. De fait, une Lettre au rédacteur en chef envoyée par Kranke et coll., ${ }^{1}$ publiée en 2000 dans Anesthesia \& Analgesia, avait soulevé de sérieuses questions concernant le caractère invraisemblable des données dans 47 articles publiés par le Dr Fujii dans cinq revues scientifiques, dont le Journal canadien d'anesthésie, au cours des années 1994-99. Dans 13 articles parmi ceux cités par Kranke et coll., la fréquence des céphalées était décrite comme identique dans tous les groupes alors que l'effet indésirable ne changeait que d'un seul patient par groupe dans les huit articles restants. L'analyse statistique de l'hypothèse nulle selon laquelle les incidences identiques décrites pourraient être 
l'effet du hasard par opposition à l'hypothèse selon laquelle une raison sous-jacente avait produit ces résultats identiques a conduit Kranke et coll. à écrire « [qu']il devait y avoir une influence sous-jacente provoquant des résultats aussi incroyablement bons dans les publications de Fujii et coll. ». ${ }^{1}$ Rétrospectivement, nous regrettons sincèrement qu'à cette époque les revues concernées n'aient pas exploré davantage cette question.

En 2011, j'ai alerté le Dr Ryoichi Ochiai, professeur d'anesthésiologie à l'École de médecine de l'université Toho pour lui faire part de nos préoccupations concernant le caractère non plausible de certains éléments dans les données présentées dans le manuscrit soumis au Journal par le Dr Fujii à propos du colforsin daropate. Cette notification a déclenché le lancement d'une enquête interne à l'université Toho. J'ai ensuite été avisé que le protocole suivi dans l'article du Dr Fujii n'avait pas reçu l'approbation d'un comité d'éthique et qu'il n'y aurait aucun moyen de prouver l'authenticité des données ou la validité de l'étude elle-même. Le Journal a rejeté cet article à la suite des investigations menées dans le département, laissant à l'Université le soin de déterminer d'autres actions éventuelles. Peu après, une révision plus complète des travaux du Dr Fujii a été lancée par le Comité d'enquête de la faculté de médecine de l'université Toho. La constatation du Comité de discipline de l'université a été publiée en mars 2012 et a porté sur des études (voir l'Annexe, disponible en ligne comme document supplémentaire) publiées dans d'autres revues et menées sans l'accord d'un Comité d'éthique. Dans sa déclaration, l'Université a exonéré le coauteur, le Dr Michiyo Itakura, de toute responsabilité. L'université Toho a ensuite mis en place un Comité de discipline qui a jugé qu'un renvoi disciplinaire était approprié; le Dr Fujii a été démis rapidement de ses fonctions le 29 février 2012.

En mars 2012, l'analyse détaillée et innovante des 168 études randomisées contrôlées rédigées par le Dr Fujii entre 1999 et 2011, soit comme auteur principal, soit comme coauteur, a été publiée dans Anaesthesia. ${ }^{2}$ Cette analyse du Dr John Carlisle fournit des arguments statistiques convaincants montrant que « la distribution des variables continues et catégorielles décrite dans les articles de Fujii, concernant aussi bien les animaux que les humains, avait extrêmement peu de chances d'être due au hasard et si c'était le cas, la probabilité que cela arrive aurait été infinitésimale ». L'analyse de 28 variables sur 33 dans l'ensemble des études a montré que les distributions publiées étaient retrouvées avec des distributions attendues telles que « leur probabilité de survenue allait de 1/25 à moins de 1 sur $10^{33} »$.

$\mathrm{Au}$ nom des rédacteurs des revues concernées, le Dr Steven Shafer, rédacteur en chef d'Anesthesia \& Analgesia, a écrit aux doyens des facultés de médecine des six universités auxquelles avait été précédemment affilié le Dr Fujii pour alerter ces institutions sur ces préoccupations et les informer des articles écrits par Kranke et coll. et le Dr Carlisle. ${ }^{B}$ Il fut demandé aux universités de fournir une preuve indubitable de l'accord du Comité d'éthique et de la véracité des données pour chacune des 168 études citées dans l'article de Carlisle, et pour 23 autres articles douteux. Dans leur déclaration commune, les rédacteurs en chef ont reconnu que l'analyse serait complexe, car elle impliquait plusieurs institutions et ils insistaient sur le fait qu'en «l'absence de la documentation mentionnée, il était possible que de nombreux articles - ou leur totalité - soient rétractés en temps opportun ».

$\mathrm{Au}$ cours des mois qui ont suivi, les institutions japonaises ont publié leurs constatations. Le centre médical JA Toride a trouvé une documentation ou approbation d'un Comité d'éthique pour aucun des 49 articles écrits par le Dr Fujii pendant la période où il exerçait dans ce centre. L'université Toho a indiqué qu'il n'y avait aucune trace d'approbation par un Comité d'éthique pour huit des 25 articles qu'ils avaient analysés et, de plus, 11 de ces 25 articles étaient des synthèses qui faisaient référence à certains articles douteux du Dr Fujii. En conséquence, le Comité d'enquête n'a pas, non plus, reconnu le caractère scientifique de ces articles. L'université de médecine et dentisterie de Tokyo a enquêté sur 13 articles : trois d'entre eux ont été jugés comme ayant été des études correctement menées et pour lesquelles le nom du Dr Fujii avait été gracieusement ajouté à la liste des auteurs. L'université de Tsukuba a déclaré que cinq des 97 articles provenant de leur institution étaient légitimes, leur enquête sur les 92 articles restants suivant son cours.

Au même moment, et de façon tout à fait indépendante, la Société japonaise des anesthésiologistes a mis en place son propre Comité spécial d'enquête, constitué d'un groupe de rédacteurs représentant 23 revues scientifiques; ce Comité a analysé 212 articles rédigés par le Dr Fujii. Le Comité a enquêté sur les données originales des recherches, les cahiers de laboratoire et les dossiers pertinents conservés dans les institutions. De plus, des membres du Comité se sont entretenus avec le Dr Fujii et avec les coauteurs cités dans ses articles. Le 29 juin 2012, la Société japonaise des anesthésiologistes a publié la déclaration du Comité intitulée « Résultats de l'enquête sur les articles du Dr Yoshitaka Fujii ». ${ }^{\mathrm{C}}$ Trois articles sur les 192 énumérés dans la déclaration commune des rédacteurs en $\operatorname{chef}^{\mathrm{B}}$ ont été jugés valides (ils avaient été publiés tous les trois dans le Journal); 154 articles publiés dans plusieurs revues

\footnotetext{
$\overline{\mathrm{B}}$ http://www.aaeditor.org/Fujii_Joint_EIC_Stmt.pdf (accessed August 25, 2012).

${ }^{\mathrm{C}}$ http://www.anesth.or.jp/english/pdf/news20120629.pdf (accessed September 7, 2012).
} 
Tableau 1 Articles rétractés du Journal canadien d'anesthésie

1. Fujii Y, Tanaka H, Toyooka H. Granisetron reduces postoperative nausea and vomiting throughout menstrual cycle. Can J Anaesth 1997; 44: 489-93.

2. Fujii $Y$, Tanaka H, Toyooka $H$. Granisetron reduces the incidence and severity of nausea and vomiting after laparoscopic cholecystectomy. Can J Anaesth 1997; 44: 396-400.

3. Fujii $Y$, Tanaka H, Toyooka H. Prophylactic antiemetic efficacy of granisetron in patients with and without previous postoperative emesis. Can J Anaesth 1997; 44: 273-7.

4. Fujii $Y$, Tanaka H, Toyooka $H$. Granisetron and dexamethasone provide more improved prevention of postoperative emesis than granisetron alone in children. Can J Anaesth 1996; 43: 1229-32.

5. Fujii $Y$, Toyooka $H$, Tanaka $H$. Antiemetic efficacy of granisetron and metoclopramide in children undergoing ophthalmic or ENT surgery. Can J Anaesth 1996; 43: 1095-9.

6. Fujii Y, Toyooka H, Tanaka H. Effective dose of granisetron for preventing postoperative emesis in children. Can J Anaesth 1996; 43: 660-4.

7. Fujii $Y$, Toyooka H, Tanaka H. Antiemetic effects of granisetron on postoperative nausea and vomiting in patients with and without motion sickness. Can J Anaesth 1996; 43: 110-4.

8. Fujii Y, Tanaka H, Toyooka H. Granisetron reduces vomiting after strabismus surgery and tonsillectomy in children. Can J Anaesth 1996; 43: $35-8$.

9. Fujii $Y$, Tanaka H, Toyooka H. Prevention of postoperative nausea and vomiting with granisetron: a randomised, double-blind comparison with droperidol. Can J Anaesth 1995; 42: 852-6.

10. Fujii $Y$, Tanaka H, Saitoh $Y$, Toyooka $H$. Effects of calcium channel blockers on circulatory response to tracheal intubation in hypertensive patients: nicardipine versus diltiazem. Can J Anaesth 1995; 42: 785-8.

11. Fujii Y, Tanaka H, Toyooka H. Granisetron-dexamethasone combination reduces postoperative nausea and vomiting. Can J Anaesth 1995 ; 42: 387-90.

12. Fujii Y, Toyooka H, Amaha K. Amrinone improves contractility of fatigued diaphragm in dogs. Can J Anaesth 1995; 42: 80-6.

13. Fujii $Y$, Tanaka $H$, Toyooka $H$. Circulatory responses to laryngeal mask airway insertion or tracheal intubation in normotensive and hypertensive patients. Can J Anaesth 1995; 42: 32-6.

14. Fujii Y, Tanaka H, Toyooka H. Optimal anti-emetic dose of granisetron for preventing postoperative nausea and vomiting. Can J Anaesth 1994; 41: 794-7.

15. Fujii Y, Toyooka H, Amaha K. Nicardipine enhances diaphragmatic fatigue. Can J Anaesth 1994; 41: 435-9.

16. Fujii Y, Tanaka H, Toyooka H. Reduction of postoperative nausea and vomiting with granisetron. Can J Anaesth 1994; $41: 291-4$.

17. Fujii Y, Toyooka H, Ebata T, Amaha K. Contractility of fatigued diaphragm is improved by dobutamine. Can J Anaesth 1993; 40: 453-8.

étaient probablement frauduleux et les données manquaient pour évaluer 28 articles. Faisant suite aux constatations de ces comités d'enquête, un avis de rétractation a été publié sur le site internet du Journal le 8 septembre 2012. Il y était écrit :

« Faisant suite à l'Énoncé de préoccupations publié en ligne le 13 mars 2012, c'est avec un immense regret que le Comité éditorial réfute et retire par la présente l'article du Dr Yoshitaka Fujii cité ci-dessus pour les raisons suivantes:

1) la preuve accablante de fabrication de données constituée par le fait que la distribution des nombreuses variables décrites par le Dr Fujii dans ces études est excessivement improbable ${ }^{1,2}$; et

2) l'incapacité dans laquelle se trouve l'institution où travaille le Dr Fujii d'attester l'intégrité des données de l'étude et/ou des données menées sous ses auspices, tel qu'établi dans la demande conjointe des Rédacteurs en chef aux fins de décision du 9 avril 2012. ${ }^{\mathrm{B}}$ »

L'avis explique également que l'université de Tsukuba a confirmé la validité de trois articles ${ }^{3-5}$ publiés dans le Journal et rédigés par le $\mathrm{Dr} \mathrm{S}$. Takahashi avec pour coauteur le Dr Fujii. De plus, l'université de médecine et dentisterie de Tokyo a confirmé le caractère légitime de deux autres articles publiés dans le Journal; l'un de ces articles avait été rédigé par le Dr T. Ebata ${ }^{6}$ et l'autre par le Dr Y. Saitoh ${ }^{7}$; le Dr Fujii apparaissant comme coauteur de ces deux articles. Les cinq articles ci-dessus restent dans la littérature médicale approuvée. Des notes de rétraction individuelles pour chacun des 17 articles énumérés dans le Tableau 1 paraissent dans ce numéro du Journal. Les 17 articles du Dr Fujii énumérés dans le Tableau 2 font toujours l'objet d'une analyse par l'université. La validité des articles du Tableau 2 fait toujours l'objet d'une analyse à l'université de Tsukuba et ceux-ci sont considérés comme douteux jusqu'à la fin de leur évaluation par l'université. Les articles du Tableau 2 qui ne seront pas confirmés comme valides par l'université de Tsukuba seront rétractés.

On considère habituellement qu'il incombe aux universités d'enquêter sur les cas suspects de fraude scientifique et/ou de comportement non éthique, et de prendre les mesures disciplinaires appropriées quand de tels cas sont confirmés. C'est le devoir des revues concernées d'entreprendre les rétractions. Bien que les revues ne reconnaissent habituellement que les constatations des enquêtes menées par les institutions, dans le cas 
Tableau 2 Articles rédigés par Dr Yoshitaka Fujii dont le statut est indéterminé

1. Fujii Y, Nakayama M. A lidocaine/metoclopramide combination decreases pain on injection of propofol. Can J Anesth 2005; 52: 474-7.

2. Numazaki M, Fujii Y. Antiemetic efficacy of propofol at small doses for reducing nausea and vomiting following thyroidectomy. Can J Anesth 2005; 52: 333-4.

3. Fujii Y. Pretreatment with flurbiprofen axetil and venous occlusion to reduce pain during injection of propofol. Can J Anesth 2004; 51: 1047-8.

4. Nakano M, Fujii Y. Prevention of nausea and vomiting after dental surgery: a comparison of small doses of propofol, droperidol, and metoclopramide. Can J Anesth 2003; 50: 1085.

5. Fujii Y, Toyooka H. High-dose colforsin daropate increases diaphragmatic contractility in dogs. Can J Anesth 2002; 49; 877-9.

6. Saitoh Y, Kaneda K, Fujii Y, Oshima T. Nicorandil accelerates recovery of neuromuscular block caused by vecuronium. Can J Anesth 2001; 48: 28-33.

7. Fujii $Y$, Toyooka H. Different effects of olprinone on contractility in nonfatigued and fatigued diaphragm in dogs. Can J Anesth 2000; 47: 1243-8.

8. Hoshi T, Fujii Y, Takahashi S, Toyooka H. Effect of xenon on diaphragmatic contractility in dogs. Canadian Can J Anesth 2000; 47: 819-22.

9. Fujii $Y$, Saitoh $Y$, Tanaka H, Toyooka $H$. Ramosetron vs granisetron for the prevention of postoperative nausea and vomiting after laparoscopic cholecystectomy. Can J Anesth 1999; 46: 991-3

10. Fujii Y, Saitoh Y, Takahashi S, Toyooka H. Combined diltiazem and lidocaine reduces cardiovascular responses to tracheal extubation and anesthesia emergence in hypertensive patients. Can J Anesth 1999; 46: 952-6.

11. Fujii Y, Saitoh Y, Takahashi S, Toyooka H. Diltiazem-lidocaine combination for the attenuation of cardiovascular responses to tracheal intubation in hypertensive patients. Can J Anaesth 1998; 45: 933-7.

12. Fujii Y, Kihara S-I, Takahashi S, Tanaka H, Toyooka H. Calcium channel blockers attenuate cardiovascular responses to tracheal extubation in hypertensive patients. Can J Anaesth 1998; 45: 655-9.

13. Fujii $Y$, Saitoh $Y$, Tanaka H, Toyooka H. Prophylactic antiemetic therapy with granisetron-droperidol combination in patients undergoing laparoscopic cholecystectomy. Can J Anaesth 1998; 45: 541-4.

14. Fujii Y, Saitoh Y, Tanaka H, Toyooka H. Cardiovascular responses to tracheal extubation or LMA removal in children. Can J Anaesth 1998; 45: 178-81.

15. Fujii $Y$, Saitoh Y, Tanaka H, Toyooka H. Prevention of PONV with granisetron, droperidol or metoclopramide in patients with postoperative emesis. Can J Anaesth 1998; 45: 153-6.

16. Fujii $Y$, Toyooka H, Tanaka H. Cardiovascular responses to tracheal extubation or LMA removal in normotensive and hypertensive patients. Can J Anaesth 1997; 44: 1082-6.

17. Fujii Y, Toyooka H, Tanaka H. Prevention of PONV with granisetron, droperidol and metoclopramide in female patients with history of motion sickness. Can J Anaesth 1997; 44: 820-4.

présent, l'enquête de la Société japonaise des anesthésiologistes a amplifié et corroboré les constatations des comités d'enquêtes des universités dans lesquelles le Dr Fujii avait travaillé antérieurement. De plus, la déclaration de la Société japonaise des anesthésiologistes aborde également la façon dont le Dr Fujii a pu publier autant d'articles falsifiés. Il y est précisé qu' « afin que ses articles soient facilement acceptés par les revues, il [le Dr Fujii] a faussement déclaré que dans la plupart de ses articles, il avait étudié de grands nombres de cas dans des études randomisées, contrôlées, à double insu ». De plus, le nom de l'institution et la période de l'étude n'étaient pas spécifiés dans ses articles de telle sorte «qu'il pouvait trouver des excuses pour les données obtenues dans des hôpitaux où il avait travaillé précédemment ou à temps partiel ». Dans de nombreux articles, les comités d'éthique de la recherche des institutions affiliées n'étaient pas identifiés et le Dr Fujii donnait également à penser que de nombreux articles reposaient sur les études de multiples auteurs en plaçant les noms d'autres institutions avec la liste de ses coauteurs. La déclaration de la Société japonaise des anesthésiologistes affirme également que «toutes les falsifications sont la responsabilité du seul Dr Fujii ». La raison pour laquelle il avait inclus les noms de coauteurs était apparemment une tactique «destinée à échapper aux soupçons de fraude ».

Nous regrettons sincèrement l'impact négatif qui sera créé par la rétractation d'une telle masse de publications scientifiques dans ce journal et dans d'autres. Ces rétractations, et d'autres encore à venir, surviennent à peine un peu plus d'un an après la rétractation des articles de Boldt. ${ }^{8}$ Douze des 17 articles rédigés par le Dr Fujii qui ont été maintenant rétractés décrivent des études cliniques sur des populations adultes et pédiatriques qui évaluaient ostensiblement l'efficacité antiémétique du granisétron. Trois de ces 17 articles décrivent des résultats ayant trait à l'efficacité de diverses interventions pharmacologiques incluant la dobutamine, la nicardipine et l'amrinone dans le but d'atténuer la fatigue diaphragmatique dans un modèle canin. D'une manière générale, les pratiques et directives de santé sont rarement changées au vu des résultats d'une seule étude originale. Plus souvent, la pratique clinique n'évolue que progressivement, après une ou plusieurs analyses systématiques ou de nouvelles lignes directrices 
(résultant d'une analyse systématique). Dans le cas des articles du Dr Fujii qui ont été rétractés, il sera important de s'assurer de l'impact de sa recherche originale sur les analyses systématiques dans lesquelles elle a été incluse, car de tels résultats pourraient éventuellement fausser des décisions jusqu'à ce qu'une nouvelle analyse excluant les études problématiques soit réalisée.

Nous tenons, au nom du Comité éditorial du Journal à exprimer nos sincères remerciements aux universités japonaises qui ont entrepris la très difficile tâche que constituait cette enquête. Nous tenons à remercier particulièrement le Dr Ryoichi Ochiai, professeur d' anesthésiologie à l'université Toho, au Japon, le Dr Steven Shafer, rédacteur en chef d'Anesthesia \& Analgesia, et le Dr Steven Yentis, rédacteur en chef d'Anaesthesia. Bien qu'il sera toujours difficile de détecter un fraudeur expérimenté, nous pouvons seulement espérer qu'une plus grande supervision par toutes les universités, un respect des exigences des directives de publications validées et une plus grande rigueur dans l'évaluation éditoriale par les pairs minimiseront ou élimineront la probabilité d'une nouvelle fraude en série aussi gigantesque.

Competing interests None declared.

\section{References}

1. Kranke P, Apfel CC, Roewer $N$. Reported data on granisetron and postoperative nausea and vomiting by Fujii et al. are incredibly nice! Anesth Analg 2000; 90: 1004-7.

2. Carlisle $J B$. The analysis of 168 randomised controlled trials to test data integrity. Anaesthesia 2012; 67: 521-37.

3. Takahashi S, Fujii Y, Inomata S, Miyabe M, Toyooka H. Landiolol decreases a dysrhythmogenic dose of epinephrine in dogs during halothane anesthesia. Can J Anesth 1999; 46: 599-604.

4. Takahashi S, Fujii Y, Hoshi T, Inomata SI, Miyabe M, Toyooka H. Modifications of the hemodynamic consequences of theophylline intoxication with landiolol in halothane-anesthetized dogs. Can J Anesth 2000; 47: 265-72.

5. Takahashi S, Fujii Y, Hoshi T, Uemura A, Miyabe M, Toyooka H. Milrinone attenuates the negative inotropic effects of landiolol in halothane-anesthetized dogs. Can J Anesth 2003; 50: 830-4.

6. Ebata T, Fujii Y, Toyooka H. Dobutamine increases diaphragmatic contractility in dogs. Can J Anaesth 1992; 39: 375-80.

7. Saitoh Y, Fujii Y, Toyooka H, Amaha K. Post-tetanic burst count: a stimulating pattern for profound neuromuscular blockade. Can $\mathbf{J}$ Anaesth 1995; 42: 1096-100.

8. Miller DR. Update to readers and authors on ethical and scientific misconduct: retraction of the "Boldt" articles. Can J Anesth 2011; 58: $777-81$. 